\title{
Proximate and microbiological compositions of some foods and vegetable from food vendors at Lagos street in Benin city
}

\author{
Henrietta Obueh ${ }^{1}$, Sunday Kolawole ${ }^{2 *}$ and Jacinta Oyem ${ }^{2}$ \\ ${ }^{1}$ Biology Department, College of Education, P.M.B 1144, Ekiadolor, Benin City, Edo State, Nigeria \\ ${ }^{2}$ National Open University of Nigeria, Benin Study Centre, Benin City, Nigeria
}

\begin{abstract}
The objective of this study was to determine the proximate and microbiological compositions of some foods (cooked fried rice and moi-moi) and vegetable (pumpkinTelfairia occidentalis) commonly sold at Lagos Street in Benin City, Edo State, Nigeria. The moisture content was highest in the vegetable with $66.64 \pm 1.23 \%$ and lowest in the fried rice with $23.73 \pm 0.6 \%$. Moi-moi had the highest protein and ash contents $(43.63 \pm 0.43 \%$ and $1.54 \pm 0.10 \%)$. The vegetable had the highest fibre content of $9.07 \pm 0.10 \%$ ). Fried rice had the highest carbohydrate content of $73.98 \pm 1.53 \%$. The total heterotrophic bacteria count was highest in the moimoi $\left(7.1 \times 10^{5} \pm 0.2 \mathrm{cfu} / \mathrm{g}\right)$ and lowest in the vegetable with $3.3 \times 10^{5} \pm 0.1 \mathrm{cfu} / \mathrm{g}$. The fungal counts ranged from $1.1 \times 10^{5} \pm 0.1 \mathrm{cfu} / \mathrm{g}$ to $2.8 \times 10^{5} \pm 0.2 \mathrm{cfu} / \mathrm{g}$. Total coliform count was highest in the vegetable at $1.8 \times 10^{3} \pm 0.1 \mathrm{cfu} / \mathrm{g}$ ). The microorganisms isolated include Staphylococcus aureus, Pseudomonas aeruginosa, Escherichia coli, Enterobacter aerogenes, Bacillus subtilis, Streptococcus sp, Klebsiella sp, Vibrio cholerae, Micrococcus sp, Penicillium sp, Fusarium, sp and Aspergillus niger. Staphylococcus aureus was the most prevalent microorganism (17.9\%) and Vibrio cholerae and Micrococcus sp were the least prevalent microorganisms (1.8\%) in the food samples. The presence of microorganisms in foods sold by food vendors at Lagos Street is an important health issue and could lead to possible spread of food - borne diseases.
\end{abstract}

\section{Introduction}

Many urban dwellers obtain a significant portion of their diet from street foods which increase the street food demand in major cities [1]. The preparation and sale of street foods is an age-old activity and has reached new dimensions as a result of rapid urbanization [2]. The safety and shelf life of these street foods, some ready-to-eat, depend upon the interaction of chemical, physical and microbial factors [3]. Street foods are foods and beverages that are sold by street vendors or hawkers and the foods and beverages could be raw or cooked [4]. They include starchy samples of maize, cassava, rice, plantain and yam; legumes like cowpea and groundnut, vegetables like tomatoes, onions, pepper, carrots, pumpkin etc and animal protein like goat meat, beef and various types of fishes [4]. Street foods displayed can be contaminated easily by dust, exhaust, smoke, insects, hands of intending buyers and climatic elements [2]. Street food vending is a large source of employment in many cities of developing countries [5], contributing significantly to household incomes [6]. Street vendors are often poorly educated, unlicenced, untrained in food hygiene practices and they work under unsanitary conditions with little or no knowledge about the causes of food borne diseases [7]. Most of the foods are not protected from flies which may carry food borne pathogens like Bacillus sp, Staphylococcus sp, E. coli, Clostridium sp, Vibrio sp, Campylobacter $s p$, Listeria $s p$ and Salmonella $s p$ [8].

A social pattern characterized by increase mobility and large itinerary workers due to urbanization has caused less family and home centred activities. This situation has resulted in more street vended ready-to-eat foods taken outside home [9]. The busy and overpopulated Lagos Street in the centre of Benin City is a commercial area where street food vendors thrive in business. Foods are often exposed near the road and vehicular emission is a major source of pollution of most street vended foods [10]. This study therefore determines the proximate and microbiological compositions of the most commonly sold and consumed foods in Lagos Street. The steamy hot cooked fried rice and moi-moi are sold by women in wheel barrows as early as $7 \mathrm{am}$. Moi-moi is a local delicacy made from blended cowpea. The vegetables are either sold raw or cooked.

\section{Materials and methods}

\section{Collection of samples}

Samples of cooked fried rice, moi-moi and vegetables were randomly purchased from food vendors at the busy Lagos Street in Benin City. The street vended foods were collected into sterile polyethylene bags and taken immediately to the laboratory for proximate and microbiological analyses.

\section{Microbiological analyses}

The samples were prepared for microbial analyses in triplicates. Ten (10) g of each sample was blended aseptically using a sterile laboratory mortar and pestle and aseptically introduced into $90 \mathrm{ml}$ of sterile distilled water and shaken to give a $10^{-1}$ dilution. Serial dilutions of all the samples were carried out to $10^{-5} .0 .1 \mathrm{ml}$ of selected dilutions were plated out using pour plate method into Nutrient Agar (NA) (Lab

Correspondence to: Sunday Kolawole, National Open University of Nigeria, Benin Study Centre, Benin City, Nigeria, E-mail: kolasunde@gmail.com

Key words: proximate, microbiological, food vendors, Lagos street

Received: February 04, 2017; Accepted: March 03, 2017; Published: March 08, 2017 
M Ltd UK) for total heterotrophic count, Eosin Methylene Blue Agar (EMB) (Lab M Ltd UK) for total coliform count and Potato Dextrose Agar (PDA) (Lab M Ltd UK) with chloramphenicol for total fungal count. The NAr plates were incubated at $37^{\circ} \mathrm{C}$ for $24 \mathrm{~h}$, EMB agar for $37^{\circ} \mathrm{C}$ for $24 \mathrm{~h}$ and PDA at $25^{\circ} \mathrm{C}$ for $72 \mathrm{~h}$. All media used were prepared according to manufacturers' instructions. Confirmation of coliform organisms was carried out by inoculating colonies into lactose broth with Durham tubes at $37^{\circ} \mathrm{C}$ for $48 \mathrm{~h}$ to evaluate gas formation [9]. The lactose broth in the tubes with gas was streaked out on EMB agar at $37^{\circ} \mathrm{C}$ for $24 \mathrm{~h}$. After incubation all discrete colonies on NA, EMB agar and PDA were counted using a Techmel and Techmel colony counter and expressed as $\mathrm{cfu} / \mathrm{g}$. Bacterial isolates were identified on the basis of cultural morphology and biochemical tests according to Bergey's Manual of Determinative Bacteriology [11] and fungal isolates were identified on the basis of their macroscopic and microscopic characteristics [12].

\section{Proximate analyses}

The moisture, protein, crude fiber, fat, ash and carbohydrate (by difference) contents were analyzed according to the AOAC [13] method. The moisture was determined by drying the samples in a hot air oven at $150^{\circ} \mathrm{C}$ for $3 \mathrm{~h}$ until a constant weight was determined. Protein content was by Kjeldahl method (total \% Nitrogen $\times 6.25$ conversion factor). Ash content was determined by incinerating $5 \mathrm{~g}$ of the samples in a muffle furnace at $550^{\circ} \mathrm{C}$ for $4 \mathrm{~h}$, cooling in a dessicator and weighing. Fat content was determined by Soxhlet extraction method in ethyl ether. Crude fiber was determined by the enzymaticgravimetric method. All the proximate analyses were carried out in triplicates and calculated in percentage.

\section{Statistical analysis}

Results were calculated in triplicate data and expressed as mean \pm standard deviation. The values were analyzed statistically using analysis of variance (ANOVA) at $5 \%$ level of significance and least significant difference (LSD) was used to compare the means [14].

\section{Results}

The proximate composition of the food samples is shown in Table 1. The pumpkin vegetable had highest moisture $(\mathrm{p}<0.05)$ at $66.64 \pm$ $1.23 \%$ when compared to the fried rice $(23.73 \pm 0.60 \%)$ and moi-moi $(50.43 \pm 0.82 \%)$. The protein contents of the food samples were $0.84 \pm$ $0.15 \%$ (fried rice), $43.63 \pm 0.45 \%$ (moi-moi) and $6.43 \pm 0.40 \%$ (pumpkin vegetable). Ash content was highest in moi-moi with $1.54 \pm 0.10 \%$ and crude fiber was highest in the vegetable with $9.07 \pm 0.10 \%$. The lipid contents were $0.21 \pm 0.10 \%, 2.25 \pm 0.26 \%$ and $9.93 \pm 0.43 \%$ for the fried rice, moi-moi and vegetable respectively. Carbohydrate content was significantly different $(\mathrm{p}<0.05)$ in the food samples with fried rice $(73.98 \pm 1.53 \%)$, moi-moi $(1.37 \pm 0.20 \%)$ and pumpkin vegetable $(7.72$ $\pm 0.90 \%)$.

Total heterotrophic bacterial count was highest in the moi-moi $\left(7.1 \times 10^{5} \pm 0.2 \mathrm{cfu} / \mathrm{g}\right)$ with the fried rice $\left(4.9 \times 10^{5} \pm 0.3 \mathrm{cfu} / \mathrm{g}\right)$ and pumpkin $\left(3.3 \times 10^{5} \pm 0.1 \mathrm{cfu} / \mathrm{g}\right)$ (Table 2$)$. The total heterotrophic fungal count was $2.4 \times 10^{5} \pm 0.2 \mathrm{cfu} / \mathrm{g}$ for fried rice, $2.8 \times 10^{5} \pm 0.2 \mathrm{cfu} / \mathrm{g}$ for moimoi and $1.1 \times 10^{3} \pm 0.1 \mathrm{cfu} / \mathrm{g}$ for pumpkin vegetable. The total coliform count was lowest in the fried rice $\left(1.1 \times 10^{3} \pm 0.1 \mathrm{cfu} / \mathrm{g}\right)$ and highest in the vegetable $\left(1.8 \times 10^{3} \pm 0.1 \mathrm{cfu} / \mathrm{g}\right)$.

Nine bacterial species and three fungal species were isolated from the food samples (Table 3). Staphylococcus aureus, Pseudomonas aeruginosa, Bacillus subtilis, Klebsiella sp and Aspergillus niger were
Table 1. Mean proximate composition of food samples

\begin{tabular}{|c|c|c|c|}
\hline Parameter (\%) & Fried Rice & Moi-Moi & Pumpkin Vegetable \\
\hline Moisture & $23.73 \pm 0.60^{\mathrm{a}}$ & $50.43 \pm 0.82^{\mathrm{a}}$ & $66.64 \pm 1.23^{\mathrm{b}}$ \\
\hline Protein & $0.84 \pm 0.15^{\mathrm{c}}$ & $43.63 \pm 0.45^{\mathrm{a}}$ & $6.43 \pm 0.40^{\mathrm{b}}$ \\
\hline Ash & $0.17 \pm 0.10^{\mathrm{b}}$ & $1.54 \pm 0.10^{\mathrm{b}}$ & $0.21 \pm 0.15^{\mathrm{b}}$ \\
\hline Crude Fiber & $0.53 \pm 0.23^{\mathrm{a}}$ & $0.78 \pm 0.10^{\mathrm{a}}$ & $9.07 \pm 0.10^{\mathrm{b}}$ \\
\hline Lipid & $0.21 \pm 0.10^{\mathrm{a}}$ & $2.25 \pm 0.26^{\mathrm{c}}$ & $9.93 \pm 0.43^{\mathrm{b}}$ \\
\hline Carbohydrate & $73.98 \pm 1.53^{\mathrm{b}}$ & $1.07 \pm 0.20^{\mathrm{a}}$ & $7.72 \pm 0.90^{\mathrm{a}}$ \\
\hline
\end{tabular}

Note: Mean \pm standard deviation of values $(n=3)$. Mean within columns with the same superscripts are not significantly different $(\mathrm{p}>0.05)$

Table 2. Mean microbial counts (cfu/g) of food samples

\begin{tabular}{|c|c|c|c|}
\hline Sample & THBC & THFC & TCC \\
\hline Fried Rice & $4.9 \times 10^{5} \pm 0.3^{\mathrm{a}}$ & $2.4 \times 10^{5} \pm 0.2^{\mathrm{a}}$ & $1.1 \times 10^{3} \pm 0.1^{\mathrm{b}}$ \\
\hline Moi-Moi & $7.1 \times 10^{5} \pm 0.2^{\mathrm{b}}$ & $2.8 \times 10^{5} \pm 0.2^{\mathrm{a}}$ & $1.7 \times 10^{3} \pm 0.1^{\mathrm{a}}$ \\
\hline Pumpkin & $3.3 \times 10^{5} \pm 0.1^{\mathrm{c}}$ & $1.1 \times 10^{5} \pm 0.1^{\mathrm{b}}$ & $1.8 \times 10^{3} \pm 0.1^{\mathrm{b}}$ \\
\hline
\end{tabular}

Table 3. Distribution of microorganisms in food samples

\begin{tabular}{|c|c|c|c|}
\hline Microorganisms & Fried Rice & Moi-moi & Pumpkin \\
\hline Staphylococcus aureus & + & + & + \\
\hline Pseudomonas aeruginosa & + & + & + \\
\hline E.coli & - & - & + \\
\hline Enterobacter aerogenes & - & + & - \\
\hline Bacillus subtilis & + & + & + \\
\hline Streptococcus $s p$ & + & + & - \\
\hline Klebsiella $s p$ & + & + & + \\
\hline Vibrio cholerae & - & - & + \\
\hline Micrococcus $s p$ & - & + & - \\
\hline Penicillium $s p$ & + & + & - \\
\hline Fusarium $s p$ & + & + & - \\
\hline Aspergillus $n$ niger & + & + & + \\
\hline
\end{tabular}

present in all the food samples. E.coli and Vibrio cholerae were only encountered in the pumpkin vegetable and Enterobacter $s p$ was only found in the moi-moi. Penicillium sp, Fusarium sp and Streptococcus $s p$ were absent in the pumpkin vegetable.

In Table 4 is presented the frequency and percentage occurrence of the microorganisms in the food samples. Staphylococcus aureus was the most prevalent microorganism (17.9\%) and Vibrio cholerae and Micrococcus $s p$ were the least prevalent species with percentage prevalence of $1.8 \%$

\section{Discussion}

The food samples analyzed in this study are the frequently purchased street vended foods in Lagos streets. The fried rice and moimoi are purchased early from food vendors on the way to work and the vegetables when returning from work. The nutrients derived in these ready to eat street vended foods are of importance and determines the quality of the food [15]. The moisture content of a food sample shows the shelf life stability of the product. The moisture contents of the food samples were high. Moisture content in excess of $14 \%$ in foods has danger of bacteria action and mould growth to produce undesirable changes [16]. The moisture content of the pumpkin was within the range of $58-93 \%$ of leafy vegetables [17]. The higher moisture content of the pumpkin when compared to the other food samples show that the vegetable has low storage capacity and is easily perishable, though the high moisture content will enhance food digestion and peristaltic movement on consumption [18]. The protein content of the moi-moi in 
Table 4. Frequency and percentage occurrence of microorganisms in food samples

\begin{tabular}{|c|c|c|c|c|}
\hline \multirow{2}{*}{ Microorganisms } & \multicolumn{3}{|c|}{ Samples/percentage occurrence (\%) } & $\begin{array}{c}\text { Total percentage } \\
\text { occurrence (9\%) }\end{array}$ \\
\cline { 2 - 4 } & Fried Rice & Moi-Moi & Pumpkin & $10(17.9)$ \\
\hline Staphylococcus aureus & $2(20.0)$ & $5(50.0)$ & $3(30.0)$ & $7(12.5)$ \\
\hline Pseudomonas aeruginosa & $3(42.9)$ & $3(42.9)$ & $1(14.2)$ & $3(5.4)$ \\
\hline E.coli & $0(0.0)$ & $0(0.0)$ & $3(100.0)$ & $2(3.6)$ \\
\hline Enterobacter aerogenes & $0(0.0)$ & $2(100.0)$ & $0(0.0)$ & $5(8.9)$ \\
\hline Bacillus subtilis & $2(40.0)$ & $1(20.0)$ & $2(40.0)$ & $2(3.6)$ \\
\hline Streptococcus sp & $1(50.0)$ & $1(50.0)$ & $0(0.0)$ & $4(7.1)$ \\
\hline Klebsiella sp & $1(25.0)$ & $2(50.0)$ & $1(25.0)$ & $1(1.8)$ \\
\hline Vibrio cholerae & $0(0.0)$ & $0(0.0)$ & $1(100.0)$ & $1(1.8)$ \\
\hline Micrococcus sp & $1(100.0)$ & $0(0.0)$ & $0(0.0)$ & $6(10.7)$ \\
\hline Penicillium $s p$ & $2(33.3)$ & $4(66.7)$ & $0(0.0)$ & $7(12.5)$ \\
\hline Fusarium $s p$ & $4(57.1)$ & $3(42.9)$ & $0(0.0)$ & $8(14.3)$ \\
\hline Aspergillus niger & $3(37.5)$ & $2(25.0)$ & $3(37.5)$ & $56(100.0)$ \\
\hline Total Isolates & $19(33.9$ & $23(41.1)$ & $14(25.0)$ & \\
\hline
\end{tabular}

this study is higher than the $21.89 \%$ and $20.50 \%$ crude protein content in the studies of Akusu and Kiin -Kabari [19] and Ejima and Ejima [20]. The protein quality of a diet is usually a measure of the ability to promote growth. This makes the moi-moi nutritionally balanced when purchased with the fried rice which is of low protein content but high carbohydrate content. Animal protein is seldom affordable by the poor in developing countries. Plants sources like moi-moi provide a cheap source of protein [21].

This study revealed a low fat content when compared to other studies for moi-moi at $15.25 \%$ [19] and $4.80 \%$ [20], cooked rice at $4.00 \%$ [22] and vegetable at $14.04 \%$ [18]. High lipid content with high moisture as seen in the pumpkin vegetable in this study increases the chances for rancidity and thus decreases the shelf life of the food [23]. The lower ash content in the fried rice and vegetable samples when compared to other studies is indicative of low mineral content [24] and hence influences its quality. The crude fiber content in the pumpkin was lower than the $10.36 \%$ in the study of Effiong et al. [18]. The fiber content is beneficial as fiber in food helps eliminate bile acids, lower body cholesterol and creates variation in feacal bulk and transit time [16]. High fiber diet intake prevents diet related diseases like cardiovascular disease, cancer of the colon and diabetes [25]. Diet with high fiber content have been used for weight control and fat reduction as it provides satiety and thereby reduces the amount of energy given food that would be consumed [26]. This could be an advantage as cooked pumpkin and salad vegetables are often sold along with fried rice, moi-moi and beans at Lagos Street.

The high microbial count recorded in the food samples could be linked to a number of factors such as improper handling and processing conditions, use of contaminated water during cooking, cross contamination of raw materials used during production, use of dirty processing utensils and unhygienic nature of food vendors [2]. The mean microbial count from the study is unacceptable as it exceeds the recommended standard of $<10^{5} \mathrm{cfu} / \mathrm{g}$ for ready-to-eat foods $[27,28]$. The microorganisms isolated in this study were in agreement with the studies of Odu and Imaki [9], Akinnibosun and Airiohuodion [8] and Ike et al. [2]. The presence of E.coli in the pumpkin vegetable indicates direct or indirect faecal contamination and this point to poor hygiene practices by the food vendors. E.coli strains pose food safety problems as they are all enterotoxigenic and cause gastroenteritis [29]. Staphylococcus aureus was the most prevalent microorganism and its presence in the food is an indication of excessive human handling [30]. Contamination of ready-to-eat by Staphylococcus aureus can be prevented through the use of latex gloves to reduce excessive human hand contact [31]. Presence of Bacillus, Klebsiella and Pseudomonas species, known to be environmental contaminants in the food samples could be due to the high rate of exposure of the food items by the food vendors to airborne and dust contaminants [2]. They were isolated in all the food samples. Bacillus sp produces toxins that withstand high temperature and are spore forming. Ingestion of the toxin-containing food causes nausea, vomiting, abdominal cramps and diarrhea [32]. Klesiella sp causes severe infections that include meningitis, bronchitis, pneumonia and urinary tract infections in human [33].

Aspergillus niger was the most prevalent fungus and its presence in the food may be hazardous to public health. Aspergillus species cause aspergillosis in patients with weakened immune systems [34]. According to Mensah et al. [35], 37.5\% of the vendors in Accra harboured at least one enteric bacterium such as E.coli and Salmonella. This is in agreement with the findings of this study where there were three enteric organisms among the nine bacteria isolated. The food vendors continuously stay by road sides in order to attract consumers thereby exposing the food to microbial contamination. The microbiological quality and safety of ready-to-eat vended foods are influenced by processing steps and storage conditions that introduce microorganisms [9], also the poor hygiene and handling by the vendors increase the contamination of the foods. The presence of Vibrio cholerae in the pumpkin vegetable showed contamination of the water used in processing the vegetable or insufficient heating of the vegetable. Effective cooking would destroy their presence [36]. Since most fresh vegetables retain their freshness for a short time, it is always better to buy vegetables in morning or evening hours depending on harvesting pattern [37]. The presence of the highest number of microbial isolates in the moi-moi depicts deplorable poor hygiene and sanitary practices employed in the processing and handling of the food and also the use of poor quality grains and leaves [38].

\section{Conclusion}

The isolation of pathogenic microorganisms from the commonly purchased foods vended in Lagos Street could pose serious health hazards to consumers. Poor handling, poor hygiene and care during and after preparation, poor storage and preservation of food and exposure of vended foods were some of the reasons for contamination of the street ready-to-eat food. Health education of vendors and consumers of street vended foods is therefore necessary in order to maximally reduce contamination of foods.

\section{References}

1. Pikuda OO, Ilelaboye NOA (2009) Proximate composition of street snacks purchased from selected motor parks in Lagos. Pakistan Journal of Nutrition 8: 1657-1660.

2. Ike CC, Emeka-Ike PC, Nwokorie CC, Anochie CC (2015) Microbiological Quality Evaluation of locally prepared snacks sold in Aba metropolis, Abia State, Nigeria. International Journal of Scientific Engineering and Applied Science 1: 46-59.

3. Oranusi S, Omagbemi F, Eni AO (2011) Microbiological safety and evaluation of snacks sold in fast food shops in Ota, Ogun State, Nigeria. International Journal of Agricultural and Food Science 1: 75- 79.

4. Ameko E, Achio S, Alhassan S, Kassim A (2012) Microbiology safety of raw mixed vegetable salad sold as an accompaniment to street vended cooked rice in Accra Ghana. Afr J Biotechnol 11: 11078-11085.

5. Choudhury M, Mahanta L, Goswani J, Mazumder M, Pegoo B (2011) Socioeconomic profile and food safety knowledge and practice of street food vendors in the city of Guwahati, Assam, India. Food Control 22: 196-203.

6. Feglo P, Sakyi K (2012) Bacterial contamination of street vending food in Kumasi, Ghana. Journal of Medical and Biomedical Science 1: 1-8.

7. Barro N, Bello AR, Itsiembou Y, Savadogo A, Ouattara CAT (2007) Street vended foods improvement: contamination mechanisms and applications of food safety objective strategy. Critical Review 6: 01-10. 
8. Akinnibosun FI, Airiohuodion P (2015) Microbial assessment and proximate analysis of pop corn sold along Benin - Sapele expressway, Nigeria. J Chem Biol Phys Sci 5: 1711-1718.

9. Odu NN, Imaku LN (2013) Assessment of the microbiological quality of street vended ready-to-eat bole (roasted plantain) fish (Trachurus trachurus) in Port Harcourt metropolis, Nigeria. Researcher 5: 9-18.

10. Opeolu BO, Adebayo PA, Okunneye PA, Badru FA (2010) Physicochemical and microbial assessment of road side food and water samples in Lagos and environs. Journal of Applied Science and Environmental Management 14: 29-34.

11. Holt JG, Krieg NR, Sneath PHA, Stanley JT, Williams ST (1994) Bergey's Manual of Determinative Bacteriology Williams and Wilkins Co. Baltimore Maryland, $9^{\text {th }}$ edition pp: 1994.

12. Tsuneo W (2010) Pictorial atlas of soil and seed fungi: Morphologies of cultural fungi and key to species. 3rd edition, CRC Press.

13. AOAC (2005) Association of Official Analytical Chemists. Official Methods of Analysis, 18th edition, Washington DC, USA.

14. Ogbeibu AE (2005) Biostatistics. A practical approach to research and data handling. Mindex Publishing Co. Ltd., Benin City, pp: 264.

15. Dosumu OO, Oluwaniyi OO, Awolola GV, Oyedeji OO (2012) Nutritional Composition and Antimicrobial properties of three Nigerian Condiments. Nigerian Food Journal 30: 43-52.

16. Ihekoronye AI, Ngoddy PO (1985) Integrated food science and technology for the tropics, Macmillian Publishers, Ltd, London pp: 293-298.

17. Osagie AU, Eka AU (1996) Nutritional quality of plant foods. Ambik Press pp: 120133.

18. Effiong GS, Ogban PI, Ibia TO, Adam AA (2009) Evaluation of nutrient -supplying potentials of fluted pumpkin (Telfairia occidentalis, Hook, F) and Okra (Abelmoschus esculentus) (L) Moench. Academic Journal of Plant Sciences 2: 209-214.

19. Akusu OM, Kiin-Kabari DB (2012) Protein quality and sensory evaluation of moi-moi prepared from cowpea/maize flour blends. African Journal of Food Science 6: 47-51.

20. Ejima OAW, Ejima OS (2015) Nutritional potential of improve fresh maize moi-moi compared with bean moi-moi. Int J Innov Res Sci Eng Technol 2: 559-572.

21. Frank-Peterside N, Dosumu DO, Njoku HO (2002) Sensory evaluation and proximate analysis of African Yam Bean (Sphenostylis stenocarpa Harms) moi-moi. Journal of Applied Science and Environmental Management 6: 43-48.

22. Idowu AO, Omobuwajo TO, Falade KO (2010) Production proximate analysis and shelf life studies of ready-to-eat rice and kilishi. African Journal of Food Science 4: 264-268.

23. Ashiedu JJ (1998) Processing and tropical crops. Macmillian Publishers Ltd London and Basingstoke.
24. Oranusi S, Braide W, Eze UC, Chinakwe E (2013) Quality aspects of African salad Journal of Emerging Trends in Engineering and Applied Sciences 4: 287-292.

25. Perreira MA, Pins JJ (2000) Dietary fiber and cardiovascular disease: experimental and epidemiologic advances. Current Atherosclerosis Reports 2: 494-502.

26. Ekop AS (2004) Effects of processing on the chemical composition of maize. Proceedings of abstract, 24th Annual Conference of Nigeria Society of Biochemistry and molecular Biology, University of Calabar, Nov. 24th -27 th.

27. Okeke KS, Bello ZA, Akoma O (2014) Evaluation of nutritional and microbial quality of three varieties of Dankuwa: A Nigerian cereal snack. Br J Appl Sci Technol 4: 45584565 .

28. Jørgensen F, Sadler-Reeves L, Shore J, Aird H, Elviss N, et al. (2017) An assessmen of the microbiological quality of lightly cooked food (including sous-vide) at the point of consumption in England. Epidemiol Infect pp: 1-10. [crossref]

29. Adu-Gyamfi A, Nketsia-Tabiri J (2007) Microbiological studies of macaroni and vegetable salads in Waakye, a local street food. Ghana J of Science 47: 3 - 9 .

30. Adamolekun WE, Adamolekun B (1992) Bacterial associated with food processing. Nigerian Medical Practice 24: 43-45.

31. Amusan E, Oramadike CK, Abraham-Olukayode AO, Adejoriwo OA (2010) Bacteriological quality of street vended smoked Blue Whiting (Micromesistus poutasou). Internet Journal of Food Safety 12: 122-126.

32. Adebayo-Tayo BC, Onilede AA, Ogunjobi AA (2006) Bacteriological and proximate analysis of periwinkle from two different creeks in Nigeria. World Applied Science Journal 1: 87-91.

33. Lau HY, Clegg S, Moore TA (2007) Identification of K. pneumonia genes uniquely expressed in a strain virulent using a murine model of bacterial pneumonia. Microbial Pathogenesis 42: 148-155.

34. Adebayo-Tayo BC, Odu NN, Igiwiloh NJPN, Okonkwo IO (2012b) Microbiological and physicochemical level of fresh cat fish (Arius hendelotic) for different markets in Akwa Ibom State, Nigeria. New York Science Journal 5: 46-52

35. Mensah P, Yeboah-Manu D, Owusu-Darko K, Ablordey A (2002) Street foods in Accra, Ghana: how safe are they? Bull World Health Organ 80 (7): 546-554. [crossref]

36. NSW Food Authority (2009) Microbiological quality guide for ready-to-eat foods, a guide to interpreting microbiological results. Food Authority of New South Wales, Australia.

37. WHO (2015) Food Safety: What you should know. World Health Organisation, World Health Day 2015.

38. Monday IE, Francis JI, Mohammed SU (2014) Microbiological quality of ready-to-eat foods (rice and moi-moi) sold by food vendors in Federal Polytechnic Bali, Taraba State Nigeria. IOSR J Environ Sci Toxicol Food Technol 8:145-149.

Copyright: (C2017 Obueh H. This is an open-access article distributed under the terms of the Creative Commons Attribution License, which permits unrestricted use, distribution, and reproduction in any medium, provided the original author and source are credited. 